\title{
FIRST RECORD OF THE FAMILY CITHAERONIDAE SIMON (ARACHNIDA, ARANEAE) FROM CUBA, IN THE CARIBBEAN REGION
}

\author{
Alexander Sánchez Ruiz and Antonio D. Brescovit
}

Laboratório Especial de Coleções Zoológicas, Instituto Butantan, Av. Vital Brasil, 1500, Butantã, São Paulo, São Paulo, Brazil, 05503-900. alex.sanchezruiz@hotmail.com; adbresc@terra.com.br

\section{ABSTRACT}

The species Cithaeron praedonius O. P.-Cambridge is recorded from eastern Cuba. This is the first record of the family Cithaeronidae in the Caribbean Region. The presence in Cuba of this species is an accidental introduction, but its source is unknown.

Key words: Cithaeronidae, new record, Cuba, Caribbean.

Título: Primer registro de la familia Cithaeronidae Simon (Arachnida, Araneae) para Cuba, en la Región del Caribe.

\section{RESUMEN}

La especie Cithaeron praedonius O. P.-Cambridge es registrada para el Este de Cuba. Este es el primer registro de la familia Cithaeronidae en la Región del Caribe. La presencia en Cuba de esta especie se considera una introducción accidental, su fuente es desconocida.

Palabras clave: Cithaeronidae, nuevo registro, Cuba, Caribe.

Cithaeronidae are fast moving spiders which hunt actively at night. They are included in the superfamily Gnaphosoidea, together with Ammoxenidae, Gallieniellidae, Trochanteriidae, Prodidomidae, Lamponidae and Gnaphosidae (Platnick, 1990; 2002). The family was revised by Platnick (1991) recognizing a total of five species in two genera (Cithaeron O. P.-Cambridge, 1872 and Intheron Platnick, 1991). Afterwards two species were described: Cithaeron indicus Platnick \& Gajbe, 1994 and Cithaeron contentum Jocqué \& Russell-Smith, 2011 from India and South Africa respectively. While Inthaeron occurs only in India, members of the genus Cithaeron can be found in Africa, Greece, Iran, Turkmenistan, Israel, Saudi Arabia, Yemen, Turkey, India, Malaysia, Australia Brazil and USA (Platnick \& Gajbe, 1994; Carvalho et al., 2007; Edwards \& Stiles, 2011; Akpinar \& Varol, 2012; Platnick, 2013).

We present here the first record of a Cithaeronidae species from the Caribbean Region. During a field trip in the Ecological Reserve Siboney-Juticí located in southeastern Cuba, approximately $10 \mathrm{~km}$ southeast of Santiago de Cuba city, two adult females of C. praedonius O. P.-Cambridge were captured (Figs. 1-4). The specimens were located at night under rocks of medium size around the Field Station Emil Racovitza (19 $57^{\prime} 40.032^{\prime \prime}$ N-7542'54.556” W) in the Protected Area. Specimens were deposited in the Arachnida collections of Instituto Butantan, São Paulo (IBSP 163682) and Centro Oriental de Ecosistemas y Biodiversidad, Santiago de Cuba (BSC-AR433).

Carvalho et al. (2007) and Edwards \& Stiles (2011), who recorded the species from the New World, considered the presence of $C$. praedonius in Brazil and USA as accidental 

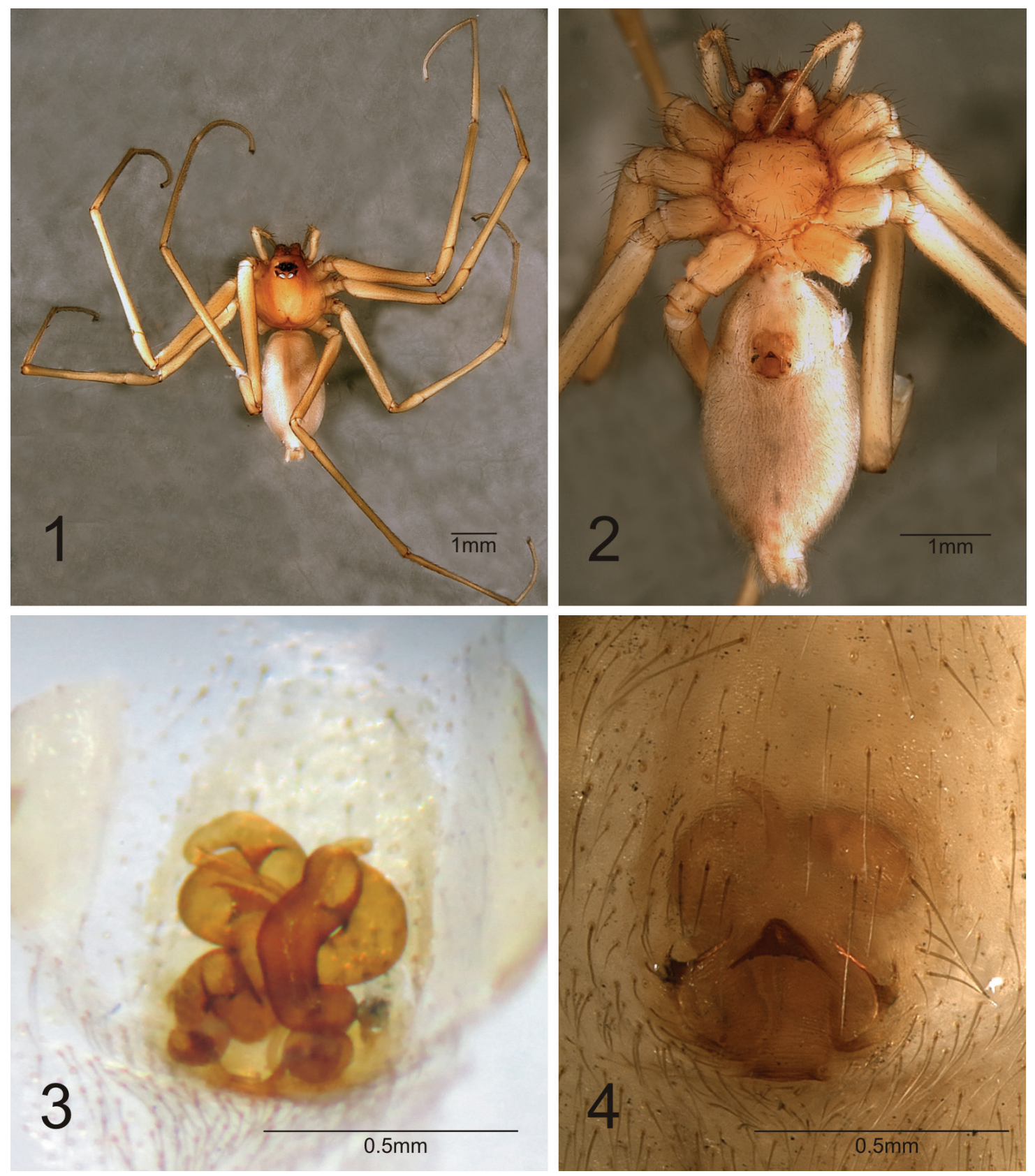

Figures 1-4. Cithaeron praedonius O.P.-Cambridge, female (IBSP 163682) from Field Station Emil Rakovitza, Ecological Reserve Siboney-Jutici, Santiago de Cuba, Cuba. Nov 3, 2010, col: A. Sánchez: 1. dorsal view; 2. ventral view; 3. epigynum, dorsal; 4. epigynum, ventral.

introduction respectively. We agree that its presence in Cuba could be due the same cause. The Ecological Reserve Siboney-Juticí retains all of its original terrestrial habitats, including coastal and precoastal xeromorphic scrub and semideciduous microphyll forest, the two most important vegetation types for conservation in the area (Fong et al. 2005). However, C. praedonius was captured in a secondary xeromorphic scrub around the Field Station, which is visited by a significant number of tourists and biologists in a year, and received several donations of 
equipments and materials from Europe. Field Station is just $1 \mathrm{~km}$ from the town of Siboney which many international tourists rent houses throughout all over the year. The source of this introduction is unknown, but due to the synanthropic environment of the collecting site and its proximity to the town of Siboney, is possible that one (or several) gravid females, arriving in suitcases of tourists or in containers with donations equipments, have been able to survive in the area.

\section{ACKNOWLEDGMENT}

This work was financially supported by Fundação de Amparo à Pesquisa do Estado de São Paulo, (FAPESP Grants 2011/50689-0 and 2012/09680-1 to ADB and ASR respectively).

\section{LITERATURE CITED}

Akpinar, A. and I. Varol. 2012. First record of family Cithaeronidae (Arachnida: Araneae) from Turkey. Serket 13: 104-107.

Carvalho, L.S., A. B. Bonaldo and A. D. Brescovit. 2007. The first record of the family Cithaeronidae (Araneae, Gnaphosoidea) to the new world. Revista Brasileira de Zoologia, 24(2): 512-514.

Edwards G. B. and J. T. Stiles. 2011. The first North American records of the synanthropic spider Cithaeron praedonius O. P.-Cambridge (Araneae: Gnaphosoidea: Cithaeronidae), with notes on its biology. Insecta Mundi 0187: 1-7.

Fong G., A., D. Maceira F., W. S. Alverson, and J. M. Shopland, eds. 2005. Cuba: SiboneyJuticí. Rapid Biological Inventories Report 10. The Field Museum, Chicago.

Platnick, N. I. 1990. Spinneret morphology and the phylogeny of ground spiders (Araneae, Gnaphosoidea). American Museum Novitates 2978: 1-42.

Platnick, N. I. 1991. A revision of the ground spider family Cithaeronidae (Araneae, Gnaphosoidea). American Museum Novitates 3018: 1-13.

Platnick, N. I. 2002. A revision of the Australasian ground spiders of the families Ammoxenidae, Cithaeronidae, Gallieniellidae, and Trochanteriidae (Araneae: Gnaphosoidea). Bulletin of the American Museum of Natural History 271: 1-243.

Platnick, N. I. 2013. The world spider catalog, version 13.5. American Museum of Natural History, online at http://research.amnh.org/iz/spiders/catalog. DOI: 10.5531/db.iz.0001. Accessed: May 1, 2013.

Platnick, N. I. and U. A. Gajbe. 1994. Supplementary notes on the ground spider family Cithaeronidae (Araneae, Gnaphosoidea). Journal of Arachnology 22: 82-83.

[Recibido: 18 de Julio, 2013. Aceptado para publicación: 19 de agosto, 2013] 